DOI https://doi.org/10.18551/rjoas.2021-01.04

\title{
STRATEGIES TO TARGET MARKET SEGMENTS FOR TRADITIONAL FOOD PRODUCTS IN SURABAYA BASED ON COWORKING SPACE
}

\author{
Siswati Endang \\ Faculty of Economics and Business, Bhayangkara University Surabaya, Indonesia \\ E-mail: endang@ubhara.ac.id \\ ORCID: 0000-0001-6902-915X
}

\begin{abstract}
This research was conducted in Surabaya and took-up coworking areas in three coworking space business models, namely: coworking satu atap business model, coworking Sub.co, and coworking NIN3 Space. The purpose of this research which is to find out how the strategy in targeting market segments in the coworking space business. This study used a qualitative approach, and the data collection methods used were observation, interviews, documentation and also using triangulation. The results showed that the three co-working spaces aimed the same target such as start-up businessmen, groups of young people, employees, and communities, the three co-working spaces also prioritize maximum customer service. The facilities provided by the three of them are the same as services in a co-working space according to Leforestier (2009). The difference is that one-stop coworking performs a product differentiation strategy, which is to provide traditional food, including sego duro and tahu tek. In line with Tjiptono's theory, which states that differentiated marketing is that companies promote a number of products with various marketing mixes, that is designed to satisfy several market segments, so that the opportunity to satisfy the specific needs of each segment becomes greater. So that in coworking satu atap with the existence of marketing differentiation, through sego duro and tahu tek products, the market segment opportunities becomes wider. With so many cafes and coffee shops, although they are not the same, they also need to be considered, by presenting creativity and innovation so that they are not knocked down by competition.
\end{abstract}

\section{KEY WORDS}

Strategy of targeting, traditional food, market segments, co-working space.

Indonesia is an archipelago with a variety of customs, ethnicities, cultures and religions, which live side by side with one another. Likewise, the traditional food varies greatly; almost every region has unique foods that are different from one another, for example Madura satay, Coto Makassar, Soto Betawi, Lemang Medan, dodol arrowroot, and so on. This culinary diversity is a unique feature and is a distinct wealth for the Indonesian nation that is not owned by other nations. The total population of Indonesia is projected to reach 269.6 million by 2020 (inter-census population survey 2015), which is a potential market for culinary businesses; so that it becomes an economic potential that can increase national economic growth. Indonesian traditional culinary business grows and develops to compete with other modern food culinary delights, and is ready to compete in the market. The growth of micro, small and medium enterprises in the culinary sector has a positive impact on the economic growth of a country. In the face of tight culinary business competition, high creativity is required, because with this creativity, the culinary business can survive and develop profitably. The contribution of the culinary business has greater potential; this is due to changes in people's lifestyles, cultural wealth, natural resources owned by an area. For this reason, a development strategy is needed to maximize the contribution of the culinary sub-sector creative economy to the national economy and particularly to the regional economy. The development strategy is determined based on mapping and initial identification of the culinary sub-sector creative economy based on structure-conduct-performance (Metasari Kartika \& Hendarmin, 2018). Competition is the color in globalization, including competition in the culinary business. Very high competition 
causes strategy changes so fast. One of them is competition in the culinary business, the emergence of various kinds of unique foods that are packaged in the form of culinary tours and have become a culinary center trend today as a lifestyle for today's society. This very fast changing environment makes business people always carry out strategies and innovate in order to gain market share. The prospect of traditional food culinary business is very promising due to the very large population, besides that the rapid growth of traditional food culinary is also able to absorb local workers. Dharmadjie (2015), improve product quality, service, product innovation and affordable prices, add outlets, and improve good relationships with customers. On the other hand, Mashur Malaka (2014), business competition does not always have a positive impact but also has a negative impact. Besides that, the lifestyle of urban communities, especially young people, has experienced a shift, for example, young people often spend time with their friends or colleagues to do assignments or work in a restaurant or cafe. Changes in lifestyle, tastes, and habits will result in changes to the food consumed, this makes culinary business people in Indonesia, especially in the city of Surabaya, have to be creative and innovative so they can understand what consumers want, so that there is no reason for customers to look another restaurant or café. Increasing competition in the culinary business can be seen by the number of new products or outlets. It is not uncommon for strategic locations to be a struggle for business actors because this location can make it easier to market products. This has an impact on micro businesses that do not have a uniqueness or strategy so that they cannot compete. If the customer is satisfied, the customer will then do marketing by himself, namely by word of mouth marketing, this is related to research from Tryansyah (2020), which one of the results of his research is that customer satisfaction has a significant effect on the word of mouth variable.

Coworking space is a way of workplace innovation and is currently trending among start-ups spread across major cities in Indonesia, including Jakarta and Surabaya, as a place to work, collaborate, and socialize in a heterogeneous work environment. The targets of the coworking space business include groups of young people, entrepreneurs, and young professionals. Several coworking spaces in Surabaya that are frequently visited by young entrepreneurs, employees, and even students include: coworking satu atap, coworking Sub.co, and coworking NIN3 Space, only a few of these coworking spaces differentiate products by offering food products. In a study conducted by Dewi Damayanti (2017), the high need for an economical work space has made the coworking space business grow. Not only in Bandung, but in other big cities, this co-working business is growing rapidly, including in the city of Surabaya. The fast growth of the star-up business lately must be supported by the expansion of the coworking space capacity as well, Lira Parahita Agni Putri and Maya Arianti. (2016), in his research suggestion entitled evaluating coworking space businesses in the city of Bandung. So we need to target the market segment for traditional food products in Surabaya with a coworking space model. Recently, café and warkop businesses have been emerging, although they are not the same as coworking businesses, it must be noted, the fact is that cafes and warkops are often used for casual chats of business people accompanied by business lobbies, and meetings. Traditional food is also a concern of consumers, for example in the research of Hertanto dkk (2020), one of the results of his research shows that consumers have high self-confidence and an evaluation of indicators of traditional Balinese food which always follows the times. The purpose of this study is to determine how the strategy of targeting market segments in the coworking space business and whether traditional food products can increase sales turnover in the coworking space business.

\section{LITERATURE REVIEW}

Kotler, (2009), Marketing deals with identifying and meeting human and community needs. One of the definitions of marketing is fulfilling needs profitably. The goal is not not to expand sales everywhere but to know and understand customers so that these products and services match the customer and then sell themselves. Kotler (2009), one can assume there will always be sales. However, the purpose of marketing is not to expand sales everywhere, 
the purpose of marketing is to know and understand customers and then sell themselves. Marketing ideally should produce a customer who is ready to buy. All that is needed next is to provide that product or service. From this definition, it can be said that marketing is how to meet customer needs in accordance with what customers hope and want, after which the company can win the hearts of customers. Coworking satu atap, coworking Sub.co, and coworking NIN3 Space is not only done through online media but also offline, namely word of mouth, promotional programs are also designed with the aim of, among other things, to attract customers.

Tjiptono (2015), states that the most common classification of strategies is: strategy at the functional, business, and corporate levels. Strategy at the functional level includes specific functional aspects in a company such as marketing strategy, operations strategy, financial strategy and others. Strategy at the business level requires the integration of strategies at the functional level for a specific set of products or services for a specific customer segment. At the corporate level strategy it is necessary to align various strategies at the business level. The main focus on this corporate level strategy is on creating added value for shareholder value, while the main focus of strategy at the business level is increasing business value, marketing strategy which is a functional strategy oriented towards creating customer value. Segmentation is an effort to classify consumers based on their needs. The main objective is to identify a group of consumers whose needs can be met with a specific single product, so that companies can implement marketing strategies more effectively and economically (Tjiptono, 2015), the assumption that is aware of that: not all consumers are similar to each other. Sub-groups of consumers with similar behaviors, backgrounds, values and needs can be identified. The sub-groups will be smaller and more homogeneous than the market as a whole. It is easier to satisfy a small group of similar customers than it is to try to satisfy a large group of different consumers. Meanwhile, Tjiptono and Chandra (2012) have four alternatives that can be found in market segmentation, namely:

1. Undifferentiated marketing (mass marketing). This approach is often called a market aggregation strategy. This strategy is based on the philosophy of mass market, which considers a particular market as a large market with similar needs and without any individual segments. In this strategy the company tries to meet the needs of all buyers by using mass production, mass distribution and mass promotion. In this mass marketing strategy there is only one marketing mix that is used to serve all markets, thereby increasing efficiency and economies of scale, including low cost and low automatic prices, and can reach as many potential buyers as possible.

2. Differentiated marketing. That is, the company promotes a number of products with various marketing mixes designed to satisfy several market segments, so that the opportunity to satisfy the specific needs of each segment is greater. Through product variety and marketing the company can increase sales and can achieve a strong position in each segment served. In the end, re-purchases will increase because the company's products are better able to meet consumer preferences. Differentiated marketing strategies usually require high costs, including production costs, promotion, research and development, market research, business planning, and distribution management.

3. Concentrade marketing (niche marketing). That is, companies that focus their marketing on only one single market segment. This alternative strategy is suitable for small companies that are financially strapped and for companies that offer highly specialized products and services. Concentrade marketing does not allow the spread of marketing risk.

4. Micromarketing. That is, the company customizes its products and marketing programs to suit individual tastes and specific locations. Micromarketing can be in the form of local marketing, namely adjusting brands and promotions to the needs of the local customer segment. Chandra Ipta Ishano, et al (2017), analyzed the segmentation of the food consumer market in Jakarta. The results show that the demographic segmentation (gender, age, and income) shows that demographic segmentation is no longer effectively used as the main measurement in market segmentation, especially in the case of the food market in Jakarta. Thus the results of this study can be used by the owners of the associated 
coworking space to target the traditional food market share with a coworking space model. Serly Wijaya and Gunawan Adi Chandra. (2006), analyzed segmentation, target and market position. The results show that each segment has different characteristics, profiles, and behaviors which can affect consumer choice at a restaurant. Thus the results of this study can be used by the owner of the coworking space location; by means of this coworking space location should adopt all consumer behavior from various segments so that it can be accepted by consumer segments in Surabaya. The development can be directed at the design of a large parking area, a beautiful and comfortable atmosphere, and combined with traditional regional food.

The definition of coworking space can include leasing workspaces that are shared and open with other users with flexible use of time. The workspace in a coworking space is used by people with different backgrounds, including entrepreneurs, freelancers, startups, associations, consultants, investors, artists, researchers, students etc. Leforestier (2009). Various services in co-working space according to Leforestier (2009): WIFI connection, power, IT facilities Fax machine, projector, flipchart, printer, telephone, scanning, bookbinder, blackboard, paper, conference room furniture, lounge, recreation room, library, water, coffee, and snacks The goals a coworking space wants to achieve are: Cost savings; Various flexible services proposed; Interaction between colleagues; A friendly environment; Possibility to create co-working space for specific sectors; Opportunities to diversify the services offered; Creation of a worldwide community of colleagues.

Can be applied to companies who want to offer a greener environment to their innovators for efficiency. Research conducted by Susilawati and Saepul Hakkul Yakin aims to analyze traditional food marketing strategies. The results of this study indicate the current marketing strategy of marketing rengginang products, namely by mouth to mouth and by means of consumers coming directly to the owner's house to buy rengginang. Thus the results of this study can be used by the owner of the coworking space location, by providing traditional food or offering traditional food to visitors to the coworking space location.

In general, we all understand what is meant by traditional food, namely certain foods or drinks that taste unique and usually have a high taste, which are usually made by certain people from generation to generation in a certain area. For example goat satay, Jakarta porridge, gudeg Yogyakarta, Sate Madura, Semanggi Suroboyo. Traditional food is usually made from natural ingredients, is highly nutritious, healthy and safe, easy to obtain and cheap in price. In accordance with the tongue of the community so that it is believed to have a good opportunity in business. Traditional Indonesian food is all kinds of food products native to Indonesian people, although newcomers can also make it. Sometimes it is used as a complementary or snack for example tempeh, tofu, meatballs, hodgepodge, etc. Besides traditional food, there are also traditional drinks that taste fresh, for example sinom, ginger, palm sugar, and so on. The processing methods vary from simple to high complexity, including baking, roasting, smoking, ordering, steaming, sautéing, frying, or boiling. The traditional food of Indonesian society cannot be separated from the culture of the people. These foods are preferred because the taste, texture, aroma is very suitable or according to the taste of the local community. The culture that exists in the community regarding this traditional food is generally already cultured from their ancestors.

Currently, many micro-businesses have sprung up in the form of cafes or warkops, as coffee shops are called. According to Law No. 20 of 2008, a micro business is a business that has the following criteria: having a net worth of not more than IDR 50,000,000 (fifty million rupiah) and does not include land and buildings for businesses that have an annual sale of at least a lot of IDR 300,000,000, - (three hundred million rupiah). In addition to selling basic products, including food and beverages, this café and coffee shop business, with the advancement of internet technology that almost covers all regions, these cafes and warkops (coffee shops) also provide free internet services in the form of wifi (free wifi). So that the competitors of coworking space today are not only fellow coworkers but also cafes and coffee shops. At present it has even become a trend that in these cafes and warkops, star-up businesses or other business people apart from sipping the coffee's flagship coffee or warkop (coffee shop), they also lobby with their business partners, hold small meetings, 
presentations small can also be done here. The food and drinks that are sold in this cafe are varied and usually have their own characteristics and this is what distinguishes one café from another, although not infrequently the food menu sold is the same. Whereas in warkop (coffee shop), the food and drinks that are sold also vary, but there are also many warkops that sell food and drinks that are more or less the same. In this coffee shop, visitors are never empty, there are visitors who come here either for small meetings to discuss business opportunities, or just to spend time surfing enjoying the virtual world.

\section{METHODS OF RESEARCH}

This research uses a qualitative research approach. As a scientific research method, qualitative research is often used by researchers in the field of social sciences, including management. The instruments in this study were interview guidelines and field observations. Data collection techniques from primary sources are collected directly and secondary sources do not directly provide data, namely through other people or through documents. This data collection technique is done by triangulation to obtain consistent, thorough, and definite data. Then the data analysis process is carried out with the following steps: after the data is collected, data reduction is carried out, and then displays the verification data or conclusions, Sugiyono (2013).

\section{RESULT AND DISCUSSION}

This research was conducted in Surabaya and took up coworking area in three business model co-working spaces, all three are: coworking satu atap, coworking Sub.co, and coworking NIN3 Space

Table 1 - Facility of coworking satu atap, coworking Sub.co, and coworking NIN3 Space

\begin{tabular}{|c|c|c|}
\hline Coworking satu atap & Coworking Sub.Co & Coworking NIN3 Space \\
\hline $\begin{array}{l}\text { Address JI Pacar A-2 Surabaya. } \\
\text { The price of the rental package per day, work } \\
\text { space Rp. } 15,000-60,000 \text {, with facilities: wi-fi, } \\
\text { free drinks, and a food station, meeting room, } \\
\text { recreation room. The monthly rental rate is IDR } \\
750,000-1,200,000\end{array}$ & $\begin{array}{l}\text { Address JI Raya Darmo Harapan } 1 \\
\text { Surabaya. } \\
\text { The price of the rental package per } \\
\text { week is IDR } 375,000 \text {, per month is IDR } \\
1,200,000 \text {. Room with a capacity of } 6-8 \\
\text { people, the price is IDR } 150,000- \\
450,000 \text {. }\end{array}$ & $\begin{array}{l}\text { Address Jl Ketintang Madya } \\
\text { No.93 Surabaya. } \\
\text { Personal locker facilities, } \\
\text { monitors, printers, scanners, and } \\
\text { provides free coffee and tea. The } \\
\text { rental price per day, IDR 85,000. }\end{array}$ \\
\hline
\end{tabular}

Source: Observations.

From the results of interviews and observations, the three coworking spaces target more or less the same target, namely: star-up business people, groups of young people, employees, and the community and all prioritize maximum service to customers and strive to provide the best facilities. The facilities provided are more or less the same, namely: Internet, office facilities and meeting rooms, which services are almost the same as services in a coworking space according to Leforestier (2009): WIFI connection, power, IT facilities, fax machines, projectors, flipcharts, printers, telephones, scans, bookbinders, whiteboards, paper, conference room furniture, lounges, recreation rooms, libraries, water, coffee, and snacks. Of the three coworking areas, the service that distinguishes it is one-stop coworking, which is providing services with traditional food menus, including sego duro and tofu, this means that one-stop coworking carries out a product differentiation strategy, this is in line with Tjiptono's theory. (2015), which states that differentiated marketing is that companies promote a number of products with various marketing mixes designed to satisfy several market segments, so that the opportunity to satisfy the specific needs of each segment is greater. Through product variety and marketing the company can increase sales and can achieve a strong position in each segment served. Besides, marketing by word of mouth by customers is very influential on prospective new customers. In the end, re-purchases will increase because the company's products are better able to meet consumer preferences. This is in line with the research conducted by Susilawati and Saepul Hakkul, (2017), 
analyzing the traditional food marketing strategy "Rengginang" showing the marketing strategy carried out, namely by mouth to mouth and by means of buyers coming directly to buy rengginang products, so that it can increase volume. sales. However, in contrast to the results of research by Chandra Ipta Ishano, et al (2017), analyzing the food consumer market segmentation in Jakarta. The results showed that the demographic segmentation (gender, age, and income) shows that demographic segmentation is no longer effective as the main measurement in market segmentation, especially in the case of the food market in Jakarta. For traditional food products in a coworking space, demographic segmentation (gender, age and income) is still effective as a measure in market segmentation. However, with the emergence of many café and warkop (coffee shop) businesses that are currently booming as well as competitors for co-working space businesses, their presence should be reckoned with because these cafes and warkops have an equal distribution of the internet which almost covers all regions, cafes and the internet. It also provides free internet facilities so that many star-up businesses or other business people use the place as small lobbies with their business partners, presentations, and other meetings besides the low cost, the places are also found everywhere, although they are not the same.

\section{CONCLUSION}

The results of research conducted in three business coworking areas include: coworking satu atap, coworking Sub.co, and coworking NIN3 Space, By using a qualitative approach, it can be concluded that the three coworking spaces target market segments that are more or less the same, namely: star-up businessmen, youth groups, employees, and the community, all of whom also prioritize service. The facilities provided are the same, namely the Internet, office facilities and meeting rooms, which services are the same as services in a co-working space according to Leforestier (2009): WIFI connection, power, IT facilities, fax machines, projectors, flipcharts, printers, telephones, scans, bookbinders, whiteboards, paper, conference room furniture, lounges, recreation rooms, libraries, water, coffee, and snacks. What makes it different is that the coworking satu atap provides services with traditional food menus, including sego duro and tohu tek to increase sales turnover. This means that the coworking satu atap carries out a product differentiation strategy, and in accordance with Tjiptono's theory which states that differentiated marketing is that companies promote a number of products with various marketing mixes consisting of product mix, price, place, and promotional mix designed to satisfy several market segments, so that the opportunity to satisfy the specific needs of each particular segment is greater. Through product variety and marketing the company can increase sales and can achieve a strong position in each segment served. Many cafes and warkops have sprung up to be reckoned with, although these cafes and warkops are not exactly the same as the coworking business, they need to be more creative and more innovative.

From the conclusions above, it is recommended that the coworking business must maximize customer service because cafes and even coffee shops have become competitors in the coworking business. In addition to improving services, the coworking business can also increase sales through product differentiation in traditional foods that are adjusted to the traditions of the local community so that they have a special characteristic in the eyes of consumers. Present creativity and innovation so that it doesn't get knocked down by any competition.

\section{REFERENCES}

1. Anne Leforestier (2009), The Co-Working Space Concept.

2. Aribowo Doddy Hertanto, Sulhaini, Herman Lalu Edi. (2020). Effect of Flash Sale Method, Product Knowledge and in Home Shopping Tendency Toward Consumer Online Purchase Decisions. RJOAS, 6(102). DOI 10.18551/rjoas.2020-06.12.

3. Agusmuda Dharmadjie, dkk. (2015). Penentuan Segmen Pasar Produk Private Label Makanan Siap Saji. Wacana vol.18, No.03. 
4. Chandra Ipta Ishano, dkk. (2017). Segmentasi Pasar Konsumen Makanan Di Jakarta Indonesia dengan pendekatan Food Related Lifestyle. Jurnal Agribisnis. Vol.11, No.3. hal (30-147).

5. Dewi Damayanti. (2017). Corporate Branding Coworking Space di Bandung. Edutech. Vol. 16, No.2.

6. https://www.onoini.com/pengertian-coworking-space-fungsi-tujuan-konsep/

7. Kotler and Keller. (2009). Manajemen Pemasaran Edisi 12 Jilid 1. Indeks. Jakarta.

8. Lira Parahita Agni Putrin and Maya Ariyanti. (2016). Studi Model Bisnis Coworking Space di kota Bandung menggunakan bisnis model canvas. Jurnal Telkom University. Vol 1 No.2.

9. Mudiantono Soekirman, dkk. (2019). Efforts to increase marketing performance of small and medium enterprises in Central Java, Indonesia. Databox.katadata.co.id.

10. Metasari Kartika \&Hendarmin. (2018). Pemetaan Ekonomi Kreatif Subsektor Kuliner di Kota Pontianak. Jurnal Ekonomi Bisnis and Kewirausahaan Universitas Tanjungpura. Vol.7, No.1. 58-71.

11. Mashur Malaka. (2014). Praktek monopoli and persaingan usaha. Jurnal Al-'Adl. Vol. 7 No. 2.

12. Mekari. (2018). Segmentasi Pasar: Strategi Jitu untuk mengefisienkan Kinerja Marketing Anda. $\quad$ https://www.jurnal.id/id/blog/2018-segmentasi-pasar-strategi-jitu-untuk mengefisiensikan-kinerja-marketing-anda/

13. Putra Andri Tryansyah. (2020). Effect of Service Quality and Customer Satisfaction Word of Mouth in PT. Telkomsel of Palembang City. RJOAS. 8 (104). DOI 10.18551/rjoas.2020-08.20.

14. Serly Wijaya and Gunawan Adi Chandra. (2006). Analisa Segmentasi, Penentuan Target, and Posisi Pasar Pada Restoran Steak and Grill Di Surabaya. Jurnal Program Manajemen Perhotelan. Fakultas Ekonomi Universitas Kristen Petra Surabaya. Vol. 2, NO. 2, hal. 76-85.

15. Susilawati and Saepul Hakkul Yakin. (2017). Analisis Strategi Pemasaran Makanan Tradisional (Studi Kasus Industri Rengginang Di Kecamatan Sakra Pusat). Jurnal Prodi pendidikan Ekonomi FKIP Universitas Hamzanwadi.

16. Sugiyono. (2013). Metode Penelitian Kombinasi (Mixed Methods). Alfabeta. Bandung.

17. Tjiptono and Chandra. (2012). Market Positioning. Erlangga. Jakarta.

18. Tjiptono Fandy. (2015). Strategi pemasaran. Andi. Yogyakarta.

19. Undang-Undang RI No 20 Tahun 2008 Tentang Usaha Mikro, Kecil, and Menengah.

20. Valentina Kris Utami. (2017). Coworking Space di Kota Yogyakarta. Jurnal Universitas Atma Jaya Yogyakarta. http://e-journal.uajy.ac.id/id/eprint/12879. 